\title{
Analysis of Potential Drug Interactions in Liver Cirrhosis Patients
}

\section{(Analisis Interaksi Obat-obat Potensial pada Pasien Sirosis Hati)}

\author{
Annisa Farida Muti ${ }^{1 *}$, Chanica Anindya ${ }^{2}$ \\ I*Pharmacy Program, Faculty of Medicine, Universitas Pembangunan Nasional “Veteran” Jakarta, Indonesia. \\ ${ }^{2}$ Pharmacy Program, Faculty of Pharmacy, Institut Sains dan Teknologi Nasional, Jakarta, Indonesia. \\ *E-mail: afmuti@upnvi.ac.id \\ Article Info: \\ Received: 14 August 2020 \\ in revised form: 1 October 2020 \\ Accepted: 7 February 2021 \\ Available Online: 2 March 2021 \\ Keywords: \\ Drug Interactions Facts \\ Liver cirrhosis \\ Potential drug-drug interactions \\ Corresponding Author: \\ Annisa Farida Muti \\ Pharmacy Program \\ Faculty of Medicine \\ Universitas Pembangunan Nasional \\ "Veteran" Jakarta \\ 12450 \\ Indonesia \\ email: afmuti@upnvj.ac.id

\begin{abstract}
Patients with liver cirrhosis are at a high risk of drug interactions due to multi-drug combination regimens. This study analyzed the potential of drug-drug interactions in liver cirrhosis patients at Gatot Soebroto Army Hospital, Jakarta, in 2016. This study employed an observational-cross sectional design with retrospective data collection of liver cirrhosis patients' medical records. The data of potential drug-drug interactions were identified using Drug Interaction Facts 2012, including the mechanism type, the severity and, the onset of drug interactions. As many as $88 \%$ of the liver cirrhosis patients experienced potential drug-drug interactions with a total of 35 cases. The highest proportions of the cases were found in the pharmacokinetic mechanism by approximately 25 cases $(71.43 \%)$, minor severity comprising 29 cases $(82.86 \%)$ and rapid onset by 19 cases (54.29\%). The highest potential drug-drug interactions were furosemidepropranolol combination in 16 cases $(45.72 \%)$. The high incidence of potential drug interactions in patients with liver cirrhosis requires high vigilance and close monitoring of all health professionals in achieving optimal therapeutic outcomes for the patients.
\end{abstract}

Copyright (C) 2019 JFG-UNTAD

This open access article is distributed under a Creative Commons Attribution (CC-BY-NC-SA) 4.0 International license.

How to cite (APA $6^{\text {th }}$ Style):

Muti, A. F., Anindya, C. (2021). Analysis of Potential Drug Interactions in Liver Cirrhosis Patients. Jurnal Farmasi Galenika :Galenika Journal of Pharmacy (e-Journal), 7(1), 18-29. doi:10.22487/j24428744.2021.v7.i1. 2021 


\begin{abstract}
ABSTRAK
Latar Belakang: Pasien sirosis hati beresiko tinggi terhadap interaksi obat akibat penggunaan regimen kombinasi multiobat. Tujuan: Penelitian ini menganalisis interaksi obat-obat potensial pada pasien sirosis hati di Instalasi Rawat Inap RSPAD Gatot Soebroto, Jakarta tahun 2016. Bahan dan Metode: Penelitian ini menggunakan desain observasional-cross sectional dengan pengambilan data rekam medis pasien sirosis hati secara retrospektif. Data interaksi obat-obat potensial diidentifikasi menggunakan Drug Interaction Facts meliputi jenis mekanisme, tingkat keparahan dan onset terjadinya interaksi obat. Hasil: Sebanyak 88\% pasien sirosis hati mengalami interaksi obatobat potensial dengan jumlah kasus sebanyak 35 kasus. Proporsi kasus terbanyak adalah mekanisme farmakokinetika sebanyak 25 kasus $(71,43 \%)$, tingkat keparahan minor sebanyak 29 kasus $(82,86 \%)$ dan onset cepat sebanyak 19 kasus $(54,29 \%)$. Interaksi obat-obat potensial terbanyak terjadi adalah furosemid-propranolol sebanyak 16 kasus $(45,72 \%)$. Kesimpulan: Tingginya kejadian interaksi obat-obat potensial pada pasien sirosis hati memerlukan kewaspadaan yang tinggi dan pemantauan yang ketat dari semua tenaga kesehatan profesional dalam mencapai outcome terapi yang optimal bagi pasien.
\end{abstract}

Kata kunci: Drug Interactions Facts, Interaksi obat-obat potensial, Sirosis hati

\title{
INTRODUCTION
}

Cirrhosis is characterized by the presence of fibrosis and the formation of liver nodules, as a result of chronic injury, which leads to changes in the lobular organization of the normal liver. Various injuries can damage the liver including virus infections, toxins, genetics, or autoimmune processes. In each injury, the liver will initially form fibrosis without losing its function. After a long injury, most of the liver tissue becomes fibrous causing the loss of cirrhosis (Sharma and John, 2019).

In 2010, the National Vital Statistics Report showed that chronic liver diseases and liver cirrhosis ranked twelve causing deaths in the United States (Sherry et al, 2013). These two diseases resulted in approximately 35,000 deaths a year. A year later, liver cirrhosis became the ninth leading cause of death accounting for $1.2 \%$ of all deaths in the United States (Suva, 2014). In Indonesia, the death rate due to liver cirrhosis is relatively high and this is mostly related to hepatitis (Sulistyoningrum and Murtisiwi, 2020). Basic Health Research (Riset Kesehatan Dasar/ Riskesdas) in 2013 reported a prevalence of hepatitis at $1.2 \%$, twice higher than that in 2007 when the type mostly infecting the Indonesian population was hepatitis B (21.8\%) (Balitbangkes, 2013). Cirrhosis and hepatocellular carcinoma are two clinical outcomes of chronic hepatitis B that are not properly treated. The five-year cumulative incidence of cirrhosis in untreated hepatitis B patients was $8-20 \%, 20 \%$ of which developed into decompensate cirrhosis within the following five years. Meanwhile, the cumulative incidence of hepatocellular carcinoma in patients with hepatitis B who already had cirrhosis reached $21 \%$ in the $6^{\text {th }}$ year of the follow-up (PPHI, 2017). A public hospital in Indonesia also reported an average prevalence of liver cirrhosis at $3.5 \%$ of all patients treated in internal wards. Liver cirrhosis and its complications were health problems that were still difficult to overcome. The majority of liver cirrhosis patients died in the fourth or fifth decade of survival (Farida et al, 2014).

The pharmacotherapy of liver cirrhosis is very complex. Patients with liver cirrhosis are at risk for potential drug-drug interactions (pDDIs) and/ or adverse drug reactions because of the severity of their 
disease and the comorbidity associated with polypharmacy. A study of 400 liver cirrhosis patients in Switzerland showed that $21.5 \%$ of the patients had one or more drug interactions, some of which caused severe reactions and/ or the need for hospitalization. The most common adverse drug reactions resulting from drug interactions were hyperkalemia (18.2\%), hypoglycemia (17.4\%), increased risk of bleeding $(12.9 \%)$, respiratory depression $(7.6 \%)$, increased risk of kidney toxicity $(6.8 \%)$ and an increased risk of cardiac toxicity $(6.8 \%)$. Nearly $13 \%$ of all pDDIs resulted in unwanted drug reactions, and the majority of these reactions occurred in patients with the most advanced cirrhosis (Child-Pugh C), even with renal impairment. As many as $8 \%$ of the patients who experienced these unwanted drug reactions required hospital treatments (Franz et al, 2012). Lorensia et al (2016) reported the incidence of drug interactions of $27.27 \%$ as the main cause of drug-related problems in hospitalized liver cirrhosis patients at Adi Husada Hospital in Undaan Wetan Surabaya, in addition to the use of contraindication drugs. Drug interactions are a major problem in pharmacotherapy, which can lead to unwanted therapy failure. Therefore, in the clinical practice, patient safety is an important thing that must be improved by periodically identifying the drug interactions by pharmacists as efforts to remind members of other health care teams (Abu Bakar et al, 2015). Identification of drug-related problems including drug interactions is one of the duties of pharmacists in the standard section of pharmaceutical services stated in the Minister of Health Regulation No.72 of 2016 concerning Clinical Pharmacy Services in Hospitals (Peraturan Menteri Kesehatan Republik Indonesia No.72 Tahun 2016 tentang Standar Pelayanan Kefarmasian di Rumah Sakit) (Ministry of Health, 2016).

Gatot Soebroto Army Hospital, Jakarta is a type-A state hospital and is of the highest reference among the Indonesian soldiers in general and the Indonesian armies in particular; as well as providing services for general public health. Due to this reason, the researcher was prompted to investigate pDDIs in liver cirrhosis patients at the Gatot Soebroto Army Hospital, Jakarta and this research had never been done before. This research is necessary to determine the pDDIs in patients with liver cirrhosis so in order to prevent adverse effects and death and to provide recommendations related to therapy to improve the patients' quality of life.

\section{MATERIAL AND METHODS}

\section{Study Design}

This study employed an observational cross-sectional design with retrospective secondary data collection. The used secondary data were medical records of liver cirrhosis patients who were hospitalized at the Gatot Soebroto Army Hospital, Jakarta in 2016. The collected data included age, sex, types of complications of liver cirrhosis, presence or absence of ascites, degree of encephalopathy, laboratory examination results (bilirubin, albumin, and prothrombin time) and pharmacological therapy during hospitalization (drug name, dose, and route of administration). 


\section{Population and Sample}

The study population was patients diagnosed with liver cirrhosis and hospitalized at the Gatot Soebroto Army Hospital, Jakarta in 2016. Sampling was conducted purposively. The inclusion criteria included patients aged 25-80 years, using more than one type of drugs and registered as inpatient in 2016; while the exclusion criteria were patients with incomplete, unreadable and damaged medical records.

The measurement of a minimum sample used Slovin formula, where the number of population was known.

Slovin Formula: $\mathrm{n}=\frac{\mathrm{N}}{1+\mathrm{N} e^{2}}$

Where:

$\mathrm{n} \quad=$ number of minimum sample

$\mathrm{N}=$ number of known population

$\mathrm{e} \quad=$ error level

Measurement of minimum sample:

$\mathrm{n}=\frac{\mathrm{N}}{1+\mathrm{N} e^{2}}=\frac{65}{1+65.0,1^{2}}=\frac{65}{1+65.0,01}=\frac{65}{1+0,65}=\frac{65}{1,65}=39,39 \infty 40$ sample

In this research, the number of sample was added by $10 \%$ to become $43 \infty 50$ samples.

\section{Data Analysis}

The data of study subjects were classified based on the demographics (age and sex) and clinical characteristics (types of complications and Child-Pugh score). Meanwhile, the data of pDDIs were identified using the 2012 Drug Interactions Facts including mechanism types (pharmacokinetics, pharmacodynamics and unknown), the severity (minor, moderate, and major) and the onset of drug interactions (rapid and delayed). All data were analyzed in uni-variance with percentages $(\%)$ presented in the frequency distribution.

\section{RESULTS AND DISCUSSION}

\section{Patient Demographics}

Table 1 indicates that the liver cirrhosis patients were predominantly males (76.00\%) and aged 46-55 years (40.00\%). According to Shimizu et al. (2012), lifestyle and social environment contribute to the incidence of liver damage. In general, men are more likely to come into contact with viral hepatitis and to consume alcohol. In Indonesia, the most common cause of liver cirrhosis is hepatitis. Hepatitis sufferers, both men and women, do not differ significantly (Pusdatin Kemenkes RI, 2014). This is in contrast to the cases in Western countries where as many as $67.6 \%$ of male patients suffered from liver cirrhosis due to alcohol factors (Saragih et al, 2016). Bacon (2012) stated that 10-30\% of heavy alcohol drinkers will suffer from alcoholic hepatitis and if there is no intervention they can develop cirrhosis. 
Studies by Lovena et al. (2017) and Patasik et al. (2015) also reported the same results in which male patients with liver cirrhosis were greater than female ones.

Table 1. Demographics Distribution of Patients with Liver Cirrhosis at Gatot Soebroto Army Hospital, Jakarta in 2016

\begin{tabular}{cccc}
\hline Demographics & Description & $\begin{array}{c}\text { Number of Patients } \\
(\mathrm{n}=50)\end{array}$ & Percentage \\
\hline Gender & Males & 38 & $76.00 \%$ \\
& Females & 12 & $24.00 \%$ \\
Age & 26-35 year & 1 & $2.00 \%$ \\
& 36-45 year & 11 & $22.00 \%$ \\
& 46-55 year & 20 & $40.00 \%$ \\
& 56-65 year & 11 & $22.00 \%$ \\
& $>65$ year & 7 & $14.00 \%$ \\
\hline
\end{tabular}

Table 1 shows that the most liver cirrhosis patients were diagnosed in patients aged 46-55 years, as many as 20 people (40.00\%). This is similar to the research of Lovena et al. (2017) where the most liver cirrhosis patients were among the 51-60-year-old patients, by as many as 107 people (35.2\%) and a study by Patasik et al. (2015) which reported that the most liver cirrhosis patients were in the age of 5059 years (31.4\%). Patients aged 26-35 had a 0.31-time lower risk of developing liver cirrhosis (Afifah, 2019) and patients aged > 49 years have a risk of developing liver cirrhosis as much as 3.9-time higher (Nasution, 2016).

Liver cirrhosis and its complications are health problems which remain hard to solve. Most liver cirrhosis patients die in the fourth or fifth decade of survival (Farida et al, 2014). The clinical manifestations of this disease only appear years after the patient is exposed to risk factors for a long time or has experienced other liver diseases such as hepatitis. As many as $15 \%$ of patients with severe liver cirrhosis die within five years if not given treatment (Stiphany et al, 2011).

\section{Clinical Characteristic of Patients}

Table 2 shows that the most complications of liver cirrhosis were ascites found in 27 patients (40.91\%). Ascites is the most common complication of decompensated cirrhosis. This complication develops in 5$10 \%$ of the patients with decompensated cirrhosis each year. The progression of ascites in patients with liver cirrhosis is associated with a poor prognosis because $40 \%$ of the death cases occur during the first year and rise to $50 \%$ in the second year. Ascites is formed as a result of renal sodium retention because of the activation of the renin-angiotensin-aldosterone and the sympathetic nerves. As a result, a positive fluid balance occurs which causes an expansion in the volume of the extracellular fluid (EASL, 2018). Some previous studies have also reported a similar profile. A study by Lovena et al. (2017) reported that the most complications in cirrhosis patients were ascites (36.3\%) followed by hematemesis and/or melena (23.2\%). Similarly, a study by Patasik et al. (2015) also found the same result in which the most common complications of liver cirrhosis were in the form of ascites and abdominal distension, each with $20 \%$ occurrence. 
Table 2. Complication Distribution of Potential Drug Interactions in Patients with Liver Cirrhosis at Gatot Soebroto Army Hospital, Jakarta in 2016

\begin{tabular}{ccc}
\hline Complications & $\begin{array}{c}\text { Number of Cases } \\
(\mathrm{f}=66)\end{array}$ & Percentage \\
\hline Ascites & 27 & $40.91 \%$ \\
Portal Hypertension and Esophageal Varices & 17 & $25.75 \%$ \\
Liver Encephalopathy & 10 & $15.15 \%$ \\
Hepatorenal Syndrome & 6 & $9.10 \%$ \\
No Complication & 5 & $7.58 \%$ \\
Spontaneous Bacterial Peritonitis & 1 & $1.51 \%$ \\
\hline
\end{tabular}

Table 3 indicates that as many as $24(48.00 \%)$ patients with liver cirrhosis had Child-Pugh score (CPS) Grade B (7-9 points). The Child-Pugh scoring system (also known as the Child-Pugh-Turcotte score) was conceptualized by Child and Turcotte in 1964 and designed to predict mortality in patients with cirrhosis. Initially, this scoring system used five clinical and laboratory criteria to categorize patients including bilirubin serum, albumin serum, presence or absence of ascites, neurological disorders, and clinical nutritional status. However, this scoring system was then modified in which the clinical nutritional status was replaced by prothrombin time (Tsoris and Marlar, 2020).

CPS classification is essential for treatment and prediction of complications that may occur and can be used to estimate the mortality rate and life quality of patients. The CPS classification is calculated by adding up the values from laboratory and clinical data. This classification is important for treatment and to predict the possible complications. The classification is divided into three levels: grade A (score 56), grade B (score 7-9), and grade C (score 10-15). The greater the number of the values indicates the higher the degree of liver damage. CPS can also be used to estimate the mortality rate and the life quality of the patients. Patients with grade A CPS can survive for about 15-20 years, while patients with grade C CPS can survive only about 1-3 years (Sease, 2011).

Table 3. Child Pugh Score Distribution of Potential Drug Interactions in Patients with Liver Cirrhosis at Gatot Soebroto Army Hospital, Jakarta in 2016

\begin{tabular}{ccc}
\hline CPS Value & $\begin{array}{c}\text { Number of Patient } \\
(\mathrm{n}=50)\end{array}$ & Percentage \\
\hline Grade A (<7 point) & 8 & $16.00 \%$ \\
Grade B (7-9 point) & 24 & $48.00 \%$ \\
Grade C (10-15 point) & 18 & $36.00 \%$ \\
\hline
\end{tabular}

\section{Potential Drug-drug Interactions}

In this study, as many as 50 patients met the inclusion criteria. Drug therapy for each patient was analyzed for pDDIs using the 2012 Drug Interactions Facts including mechanism types (pharmaceuticals, pharmacokinetics and pharmacodynamics), the severity (minor, moderate, and major) and the onset of drug interactions (fast and delayed). The results of the analysis indicated that among the 50 patients there were 44 patients experiencing pDDIs (88\%) with a total of 35 cases. The result of 
this study indicates a higher number than that of Franz et al. (2012) result in which among 86 patients there were 132 cases of pDDIs. Seven of them were caused by unwanted drug effects, of which three cases required hospitalization.

Table 4 illustrates the pDDIs of liver cirrhosis patients at Gatot Soebroto Army Hospital, Jakarta in 2016, which was dominated by pharmacokinetics, as many as 25 cases (71.43\%). A pharmacokinetic drug interaction occurs when a drug affects the absorption, distribution, metabolism and excretion of another drug (Baxter, 2010; Hartshorn and Tatro, 2012; Corrie and Hardman, 2014). This interaction produces a response which is varied among patients and is difficult to predict (Corrie and Hardman, 2014). The pharmacokinetic drug interaction is often associated with negative effects such as unwanted drug effects, drug toxicity or insufficiency of drug concentrations in plasma. However, in some cases this interaction has potentially benefited the patient. These beneficial effects include improving drug bioavailability (through increased drug absorption and/or inhibition of drug metabolism) or prolonging drug levels within the therapeutic scope (through decreased drug excretion) (Gerber et al., 2018).

Table 4. Mechanism Distribution of Potential Drug Interactions in Patients with Liver Cirrhosis at Gatot Soebroto Army Hospital, Jakarta in 2016

\begin{tabular}{cccc}
\hline \multirow{2}{*}{ Mechanism } & Drug & $\begin{array}{c}\text { Number of Cases } \\
(\mathrm{f}=35)\end{array}$ & Percentage \\
\hline \multirow{5}{*}{ Pharmacokinetics } & Furosemide - Propranolol & 16 & \\
& Propranolol - Acetaminophen & 4 & \multirow{2}{*}{$71.43 \%$} \\
& Aspirin - Ramipril & 3 & \\
& Spironolactone - Aspirin & 1 & $11.42 \%$ \\
\hline Pharmacodynamics & Omeprazole - Vitamin B 12 $^{2}$ & 1 & \multirow{2}{*}{$17.15 \%$} \\
\hline \multirow{2}{*}{ Unknown } & Ramipril - Furosemide & 4 & \\
& Ramipril - Spironolactone & 3 & \\
& Ranitidine - Ketorolac & 2 & \\
& Aspirin - Furosemide & 1 &
\end{tabular}

The severity of pDDIs in patients with liver cirrhosis at Gatot Soebroto Army Hospital, Jakarta in 2016 was mostly minor by as many as 29 cases $(82.86 \%)$ as shown in Table 5. Severity level indicates the potential risk of the drug interaction which determines the need of further actions to be taken, so that adverse interactions can be avoided. Minor severity is mild, has almost no effect on clinical effects and may interfere with patient comfort, but does not significantly affect the outcome of the therapy. In this case, an additional therapy is generally not required (Baxter, 2010; Hartshorn and Tatro, 2012; Soherwadi et al., 2012; Bethi et al., 2018). 
Table 5. Severity Distribution of Potential Drug Interactions in Patients with Liver Cirrhosis at Gatot Soebroto Army Hospital Jakarta in 2016

\begin{tabular}{cccc}
\hline Severity & Drug & $\begin{array}{c}\text { Number of Cases } \\
(\mathrm{f}=35)\end{array}$ & Percentage \\
\hline Major & Ramipril - Spironolactone & 3 & $8.57 \%$ \\
\hline Moderate & Aspirin - Ramipril & 3 & $8.57 \%$ \\
\hline & Furosemide - Propranolol & 16 & \\
& Propranolol - Acetaminophen & 4 & \\
Minor & Ramipril - Furosemide & 4 & $82.86 \%$ \\
& Ranitidine - Ketorolac & 2 & \\
& Aspirin - Furosemide & 1 & \\
& Spironolactone - Aspirin & 1 & \\
& Omeprazole - Vitamin B B & 1 & \\
\hline
\end{tabular}

In this study, the major severity was only 3 cases (8.57\%) of the total pDDIs cases in liver cirrhosis patients at the Gatot Soebroto Army Hospital, Jakarta in 2016. Major severity can potentially be lifethreatening or cause permanent disability. These drug interactions occur with the use of the ramipril and spironolactone which can cause an increase in serum potassium concentrations in high-risk patients (e.g. impaired renal function). Therefore, it is necessary to monitor the kidney function and serum potassium levels in patients periodically, or even to adjust the dosage when needed (Baxter, 2010; Hartshorn and Tatro, 2012; Soherwadi et al., 2012; Bethi et al., 2018).

Table 6. Onset Distribution of Potential Drug Interactions in Patients with Liver Cirrhosis at Gatot Soebroto Army Hospital, Jakarta in 2016

\begin{tabular}{cccc}
\hline \multirow{2}{*}{ Onset } & Drug & $\begin{array}{c}\text { Number of Cases } \\
(\mathrm{f}=35)\end{array}$ & Percentage \\
\hline \multirow{2}{*}{ Fast } & Furosemide - Propranolol & 16 & $54.29 \%$ \\
\hline \multirow{5}{*}{ Delayed } & Aspirin - Ramipril & 3 & \\
& Propranolol - Acetaminophen & 4 & \\
& Ramipril - Furosemide & 4 & $45.71 \%$ \\
& Ramipril - Spironolactone & 3 & \\
& Ranitidine - Ketorolac & 2 & \\
& Aspirin - Furosemide & 1 & \\
\hline
\end{tabular}

According to the onset result, pDDIs in patients with liver cirrhosis at the Gatot Soebroto Army Hospital, Jakarta in 2016 were dominated by the rapid type reported as many as 19 cases (54.29\%) (as shown in Table 6). The onset time describes the rate at which the clinical effect of a drug interaction appears thereby determining the urgency of a necessary action to prevent or resolve the consequences of the drug interaction. Rapid onset is an effect that appears 24 hours after the administration of the interacting drugs. Immediate action is needed to prevent drug interactions (Baxter, 2010; Hartshorn and Tatro, 2012; Bethi et al., 2018).

The results indicated that of the three parameters (type of mechanism, severity and onset), the highest pDDIs were interactions between furosemide and propranolol in 16 cases (45.72\%). Propranolol is the 
first $\beta$ adrenoceptor inhibitor to be used clinically in its class, whose use has been shown to have beneficial cardiovascular effects in patients with hypertension, angina pectoris, myocardial infarction and congestive heart failure. On the other hand, furosemide is a loop diretic, a derivative of an anthranilic acid, which is used in the treatment of a congestive heart failure, hypertension and edema. It works by inhibiting the absorption of sodium and fluid in the renal tubules thereby increasing urine outputs (diuresis) (Zal et al., 2014).

In patients with liver cirrhosis, furosemide is used as an adjunct in the management of ascites in the patients who do not respond to spironolactone alone. The initial dose of furosemide is $40 \mathrm{mg} / \mathrm{day}$ and can be increased every 2-3 days to a dose not more than $160 \mathrm{mg} / \mathrm{day}$, in which the administration is carried out by a biochemical examination and clinical monitoring (Level A1) (EASL, 2010). On the other hand, Runyon (2012) stated that the use of a combination of spironolactone and furosemide from the beginning in the management of ascites is preferable because it aims to achieve rapid natriuresis and maintain normokalemia (Class IIa, Level A). Propranolol, a non-selective beta blocking agent, is used as a primary prophylaxis in the patients with ascites and a secondary prophylaxis in those with varicose bleeding (Reiberger and Mandorfer, 2017).

Cardiovascular system drugs have a higher potential for drug interactions (Reiberger and Mandorfer, 2017). The use of furosemide with propranolol may increase the cardiovascular effects of propranolol as a result of the reduction in extracellular fluid by furosemide. The severity of this interaction is minor, therefore, direct clinical intervention is not necessary. However, the cardiovascular status of the patients still needs to be monitored. Besides, propranolol dosage adjustments can be made if needed (Baxter, 2010; Hartshorn and Tatro, 2012).

Risk and benefit considerations are the thought on the potential bad side effects and advantages of drug administration, if two drugs are given simultaneously and have potential interactions, the consideration is made when the benefits of the two drugs given are greater than the risk of harm (Sari et al., 2012).

\section{CONCLUSION}

As many as $88 \%$ of liver cirrhosis patients at Gatot Soebroto Army Hospital, Jakarta in 2016 experienced pDDIs with a total of 35 cases. The most pDDIs were pharmacokinetic mechanisms of 25 cases (71.43\%), minor severity as many as 29 cases (82.86\%), and rapid onset in 19 cases $(54.29 \%)$. The majority of pDDIs were furosemide-propranolol in 16 cases (45.72\%). The high incidence of pDDIs in patients with liver cirrhosis requires close monitoring and high vigilance from all parties especially clinicians and pharmacists in achieving optimal therapeutic outcomes for the patients.

\section{CONFLICT OF INTEREST}

Authors declare there is no conflict of interest. 


\section{REFERENCES}

Abubakar, A. R., Chedi, B. A., Mohammed, K. G., and Haque, M. (2015). Drug interaction and its implication in clinical practice and personalized medicine. National Journal of Physiology,

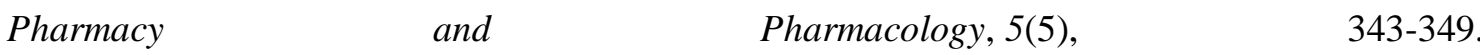
http://dx.doi.org/10.5455/njppp.2015.5.2005201557

Afifah, T. A. (2019). Faktor-faktor yang Berhubungan dengan Sirosis Hati di RSUP dr. Hasan Sadikin Bandung: Studi Analitik Periode Januari 2017-Desember 2018 (Unpublished undergraduate thesis), Universitas Jenderal Achmad Yani, Indonesia.

Bacon, B.R. (2012). Cirrhosis and Its Complications. In: Longo DL, Fauci AS, Kasper DL, Hauser SL, Jameson JL, Loscalzo J (Eds.), Harrison's Principles of Internal Medicine (18 ${ }^{\text {th }}$ ed.). Volume 2. New York: McGraw-Hill. 2592-2602.

Badan Penelitian dan Pengembangan Kesehatan Kementerian Kesehatan Republik Indonesia. (2013). Hasil Utama Riskesdas 2013. Jakarta: Kementerian Kesehatan RI.

Baxter, K. (2010). Stockley's Drug Interaction ( $9^{\text {th }}$ ed.). UK: Pharmaceutical Press.

Bethi, Y., Shewade, D. G., Dutta, T. K., and Gitanjali, B. (2018). Prevalence and predictors of potential drug-drug interactions in patients of internal medicine wards of a tertiary care hospital in India. European Journal of Hospital Pharmacy, 25(6), 317-321. http://dx.doi.org/10.1136/ejhpharm-2017-001272

Corrie, K., and Hardman, J. G. (2011). Mechanisms of drug interactions: pharmacodynamics and pharmacokinetics. Anaesthesia and Intensive Care Medicine, 12(4), 156-159. https://doi.org/10.1016/j.mpaic.2010.12.008

European Association For The Study Of The Liver. (2010). EASL clinical practice guidelines on the management of ascites, spontaneous bacterial peritonitis, and hepatorenal syndrome in cirrhosis. Journal of hepatology, 53(3), 397-417. https://doi.org/10.1016/j.jhep.2010.05.004

European Association for the Study of the Liver. (2018). EASL Clinical Practice Guidelines for the management of patients with decompensated cirrhosis. Journal of hepatology, 69(2), 406-460. https://doi.org/10.1016/j.jhep.2018.03.024

Farida, Y., Andayani, T. M., and Ratnasari, N. (2014). Analisis penggunaan obat pada komplikasi sirosis hati. Jurnal Manajemen dan Pelayanan Farmasi (Journal of Management and Pharmacy Practice), 4(2), 77-84. https://doi.org/10.22146/jmpf.270

Franz, C. C., Egger, S., Born, C., Bravo, A. E. R., and Krähenbühl, S. (2012). Potential drug-drug interactions and adverse drug reactions in patients with liver cirrhosis. European journal of clinical pharmacology, 68(2), 179-188. https://doi.org/10.1007/s00228-011-1105-5 
Gerber, W., Steyn, J. D., Kotzé, A. F., and Hamman, J. H. (2018). Beneficial pharmacokinetic drug interactions: a tool to improve the bioavailability of poorly permeable drugs. Pharmaceutics, 10(3), 106. https://doi.org/10.3390/pharmaceutics10030106

Hartshorn, E. A., Tatro, D. S. (2012). Principles of Drug Interactions. In: Tatro DS (Eds.), Drug Interaction Facts: The Authority on Drug Interactions. California: Wolters Kluwel Health Inc.

Kementerian Kesehatan Republik Indonesia (Kemenkes RI). (2016). Peraturan Menteri Kesehatan Republik Indonesia Nomor 72 Tahun 2016 tentang Standar Pelayanan Kefarmasian di Rumah Sakit. Jakarta: Kementerian Kesehatan Republik Indonesia.

Lorensia, A., Queljoe, D., Nata, F. D. (2016). Analisis Drug-related Problem (DRP) Berdasarkan Penyebab pada Pasien Sirosis Hati yang Menjalani Rawat Inap di Rumah Sakit Adi Husada Undaan Wetan Surabaya. Jurnal Ilmiah Sains and Teknologi, 10(1), 1-14.

Lovena, A., Miro, S., and Efrida, E. (2017). Karakteristik Pasien Sirosis Hepatis di RSUP Dr. M. Djamil Padang. Jurnal Kesehatan Andalas, 6(1), 5-12. https://doi.org/10.25077/jka.v6i1.636

Reiberger, T., and Mandorfer, M. (2017). Beta adrenergic blockade and decompensated cirrhosis. Journal of hepatology, 66(4), 849-859. https://doi.org/10.1016/j.jhep.2016.11.001

Nasution, K. (2016). Faktor Risiko yang Mempengaruhi Terjadinya Sirosis pada Penderita Hepatitis B di RSUP H. Adam Malik Medan Tahun 2016 (Unpublished doctoral thesis). Universitas Sumatra Utara, Indonesia.

Patasik, Y. Z., Waleleng, B. J., and Wantania, F. (2015). Profil pasien sirosis hati yang dirawat inap di RSUP PROF. DR. RD Kandou Manado periode agustus 2012-agustus 2014. e-CliniC, 3(1). https://doi.org/10.35790/ecl.3.1.2015.6841

Perhimpunan Peneliti Hati Indonesia (PPHI). (2017). Konsensus Nasional Penatalaksanaan Hepatitis B di Indonesia. Jakarta: Perhimpunan Peneliti Hati Indonesia.

Pusat Data dan Informasi Kementerian Kesehatan Republik Indonesia (Pusdatin Kemenkes RI). (2014). Situasi dan Analisis Hepatitis. Jakarta: Kementerian Kesehatan Republik Indonesia.

Runyon, B. A. (2013). Management of adult patients with ascites due to cirrhosis: update 2012. Hepatology, 57(4), 1651-3.

Saragih, G. G., Waleleng, B. J., and Haroen, H. (2016). Gambaran Gangguan Hemostasis pada Penderita Sirosis Hati yang Di Rawat Di RSUP Prof. Dr. Rd Kandou Periode Agustus 2013-Agustus 2015. e-CliniC, 4(1). https://doi.org/10.35790/ecl.4.1.2016.10945

Sari, A., Wahyono, D., and Raharjo, B. (2012). Identifikasi Potensi Interaksi Obat pada Pasien Rawat Inap Penyakit Dalam Di RSUD Prof. Dr. Margono Soekarjo Purwokerto Dengan Metode Observasional Retrospektif Periode November 2009-Januari 2010. PHARMACIANA, 2(2). http://dx.doi.org/10.12928/pharmaciana.v2i2.669.g508 
Sease, J. M. (2011). Portal Hypertension and Cirrhosis. In: Dipiro JT, Talbert RL, Yee GC, Matzke GR, Well BG, Posey LM (Eds.), Pharmacotheraphy: A Patophysiologic Approach. $8^{\text {th }}$ edition. New York: The McGraw_Hill Companies Inc. 639-57.

Sharma, B. and John, A. (2019). Hepatic Cirrhosis. Treasure Island (FL): StatPearls Publishing.

Sherry, L., Murphy, B. S., Jiaquan Xu, M. D., Kenneth, D., Kochanek, M. A. (2013). National Vital Statistics Reports, 61(4). U.S. Department Of Health And Human Services.

Shimizu, I., Matsumoto, T., Suzuki, N., Sagara, C., Koizumi, Y., Asaki, T., et al. (2012). Chronic Liver Disease Develop More Slowly in Females than Males. In: Simizu I (Eds.), Preventive Female Sex Factors against The Development of Chronic Liver Disease. Japan: Bentham eBooks. 3-18.

Soherwardi, S., Chogtu, B., and Faizal, P. (2012). Surveillance of the Potential Drug-Drug Interactions in the Medicine Department of a Tertiary Care Hospital. Journal of Clinical and Diagnostic Research, 6(7), 1258-61.

Stiphany, Hiswani, Jemadi. (2011). Karakteristik Penderita Sirosis Hati Rawat Inap di RSUD DR Pirngadi Medan Tahun 2010-2011. Jurnal Hasil Riset, Universitas Sumatera Utara, Indonesia.

Sulistyoningrum, E., and Murtisiwi, L. (2020). Gambaran Peresepan Pasien Sirosis Hati di Instalasi Rawat Jalan Rumah Sakit Panti Waluyo Surakarta. Jurnal Farmasi (Journal of Pharmacy), 9(1, Maret), 1-7. https://doi.org/10.37013/jf.v9i1,\%20Maret.96

Suva, M. A. (2014). A Brief Review on Liver Cirrhosis: Epidemiology, Etiology, Pathophysiology, Symptoms, Diagnosis and Its Management. Inventi Rapid: Molecular Pharmacology, 2014(2), 15.

Tsoris A, and Marlar CA. (2019). Use of The Child Pugh Score in Liver Disease. StatPearls Publishing.

Zal, F., Taheri, R., Khademi, F., Keshavarz, E., Rajabi, S., and Mostafavi-Pour, Z. (2014). The combined effect of furosemide and propranolol on GSH homeostasis in ACHN renal cells. Toxicology mechanisms and methods, 24(6), 412-416, https://doi.org/10.3109/15376516.2014.926437 